\title{
Access over ownership: meeting facilities in Lyngby-Taarbæk Knowledge City
}

\author{
Nielsen, Susanne Balslev; Berg, Rikke Brinkø
}

Published in:

Facilities

Link to article, DOI:

10.1108/F-01-2017-0001

Publication date:

2018

Document Version

Peer reviewed version

Link back to DTU Orbit

Citation (APA):

Nielsen, S. B., \& Berg, R. B. (2018). Access over ownership: meeting facilities in Lyngby-Taarbæk Knowledge City. Facilities, 36(1/2), 13-23. https://doi.org/10.1108/F-01-2017-0001

\section{General rights}

Copyright and moral rights for the publications made accessible in the public portal are retained by the authors and/or other copyright owners and it is a condition of accessing publications that users recognise and abide by the legal requirements associated with these rights.

- Users may download and print one copy of any publication from the public portal for the purpose of private study or research.

- You may not further distribute the material or use it for any profit-making activity or commercial gain

- You may freely distribute the URL identifying the publication in the public portal

If you believe that this document breaches copyright please contact us providing details, and we will remove access to the work immediately and investigate your claim. 


\title{
Access over ownership: Meeting facilities in Lyngby-Taarbæk Knowledge City
}

\author{
Susanne Balslev Nielsen \\ Department of Management Engineering, Technical University of Denmark, Kongens Lyngby, Denmark and \\ Oslo and Akershus University College of Applied Science, Oslo, Norway \\ Rikke Brink $\varnothing$ \\ Department of Management Engineering, Technical University of Denmark, Kongens Lyngby, Denmark \\ rikbk@dtu.dk
}

\begin{abstract}
Purpose: This study investigates the attitude towards shared space in an urban context with a particular focus on meeting facilities. The Lyngby-Taarbæk City of Knowledge is used as case, as this organisation has a vision of sharing facilities to stimulate regional development.

Methodology: The attitude towards shared space in the Lyngby-Taarbæk City of Knowledge is studied in a three-step qualitative research process. An initial survey investigated the City of Knowledge's member's attitude towards shared space in general, a workshop further explored motivations and practical needs and a second survey investigated the attitude towards shared meeting facilities. The Brink $\varnothing$ Typology of Shared Use of Space and Facilities is used as the theoretical framework for the study (Brinkø et al 2015).

Findings: This study show that the respondents are very positive towards the concept of shared space, but more reluctant when it comes to sharing own facilities. A majority of the informants are often using externally owned facilities for meetings and events, and prefer professional meeting facilities to schools, universities and sports facilities. This point to a need for developing relevant service concepts, if a shared space strategy with focus on meeting facilities were to be used to increase the use rate of existing buildings not already intended for this use.
\end{abstract}

Originality: This study adds to the so far limited amount of scientific knowledge on the topic of shared space, by investigating the attitude towards shared space among a specific group of people, in relation to the use of external meeting facilities.

Keywords: Facilities Management, property management, space management, shared space, sharing economy 


\section{Introduction}

Collaborative Consumption, access economy or the sharing economy are all terms describing the new fast growing business built on the sharing of resources and promoting access over ownership. It is a paradigm shift that has made it to the Times magazine list of the "10 ideas that will change the world" (Walsh 2011). Within this overall paradigm, shared space, is also gaining grounds in real estate management and FM, as a way for individuals and organisations to gain access to facilities without owning them and without long term leasing contracts (e.g. Meel and Brink $\varnothing 2014$; Brink $\varnothing$ et al 2015; Brink $\varnothing$ and Nielsen 2015; Kojo and Nenonen 2016; Rytkönen 2016).

Shared space is a concept that can lead to positive effects for multiple stakeholders. A user will be able to use a facility without owning the building or engaging in leasing contracts, but gain access to use a facility free of charge or for a fee for the access and use. From the perspective of a facilities manager, who has the task of ensuring a satisfactory use rate of a certain building or space, the shared space movement is a positive development which can help intensify the use of buildings that are perceived as underutilised. From a societal development perspective there is a deliberate agenda of creating lively and attractive urban environments which can stimulate cultural and economic innovation, and the increase of people using the facilities and the mix of user groups is a strategy for many innovation hubs.

From a sustainability perspective shared space holds a potential for a positive environmental effect. Especially if less new buildings are built because of shared space, then a significant environmental effect is avoided as building materials consumes resources, are energy demanding to produce and the building represents a potential waste problem once exceeding its operational phase (Cabeza et al 2014 and Nielsen et al 2016). Considering already existing buildings, the potential positive or negative effect of shared space, in relative and absolute terms, is more unclear. From a single-building perspective the environmental impact is likely to be greater due to intensified use, but this intensified use of one building should in theory be caused by less intensified use of several others, which then can be made available for other uses; leading to the possibility of fewer new buildings constructed. The effect will of course also be influenced by the condition of the buildings, meaning that if more use it moved from buildings with a poor environmental performance to buildings with a better one, this can push the effects in a positive direction, whereas the opposite is true if the use is moved from well-performing buildings to buildings with a lower environmental performance etc.

The purpose of the study is to investigate the attitude towards shared space in an urban context with a particular focus on meeting facilities. To what degree is there an interest in sharing otherwise private meeting facilities within a city or a municipality? The Lyngby-Taarbæk City of Knowledge in Greater Copenhagen, Denmark, is used as case, as this strategic collaboration on municipal level includes a vision of sharing facilities. The Lyngby-Taarbæk City of Knowledge being a private association and unique partnership between private companies, research and educational institutions, local authority, housing associations and citizens to ensure the city of Lyngby's continued growth through collaboration across traditional boundaries. Information about the Lyngby-Taarbæk City of Knowledge is available at www.vidensby.dk.

\section{Shared space}

Shared space is a relatively new topic with not much scientific literature produced so far; and even less on how it connects to facilities management and how we can optimise the use of the important resource space and buildings constitute. When looking at the field of facilities management, there are a number of topics that are of direct relevance when discussing shared space and among these is space management. 
The field of space management, with the purpose of ensuring the efficient and cost-effective use of space (Atkin \& Brooks, 2015), is very closely linked to the topic of shared spaces, since space is the physical object of the sharing. Much can be learned from existing literature within this field ranging from theory on 'new ways of working', design of open-office spaces etc. (F. Becker, 1990; F. D. Becker \& Steele, 1995; Duffy, Craig, \& Gillen, 2011; Duffy \& Powell, 1997), to theory on utilisation ratio from for example (Atkin \& Brooks, 2015; Fawcett, 2009; Jensen, 2008; May, 2014). Most of this theory though, only addresses sharing within the context of office space and rarely moves outside intra-organisational sharing.

With this in mind, additional knowledge is needed to create a better understanding of the complex processes involved in shared space, and to fulfil this gap some literature is beginning to emerge, building on the initial work by for example (Gaffikin \& Morrissey, 2011; Khamkanya \& Sloan, 2009; Lee, Kim, \& Yoon, 2010; Rafferty, 2012).

Among this literature is also The Brinkø Typology of Shared Use of Space and Facilities (Brinkø et al 2015), which will be used as the theoretical background of this study, and can be seen in figure 1. It provides an overview of 4 types of shared space and a vocabulary for categorizing a case of shared space. Each type is characterised by what is shared, when (simultaneously or serial), why, by who and how is the sharing managed. 3 of the 4 types are relevant with a focus on meeting facilities for events that are larger than a person or organisation can host at own premises. The type of sharing at the smallest scale, where you share specific facilities such as a desk or workspaces, are perceived not relevant in the case of this study. The three relevant types of shared space are:

\section{Sharing several facilities in an open or semi-closed community}

o Example: The facilities are a meeting room with reception, toilets, catering services etc. The space is open for the public to book and use, or if it is semi-closed, only to be used by certain members of certain organisations.

\section{$>$ Sharing physical space in a building or a building in itself in a closed community}

o Example: Two companies in the same building is sharing e.g. entrance, reception, cantina, and meeting rooms.

$>$ Sharing facilities between users in a network of buildings/organizations in an open, semi-closed or closed community

o Example: A network of companies in a city decided to open their meeting facilities for external users. If it in an open community, anybody can book the facilities. In a semi-closed it is only e.g. members from the network or if it is in a closed community, it is only specific organisations and you cannot obtain the right to access e.g. by becoming a member of the network. 


\section{TYPOLOGY OF SHARED USE OF FACILITIES}

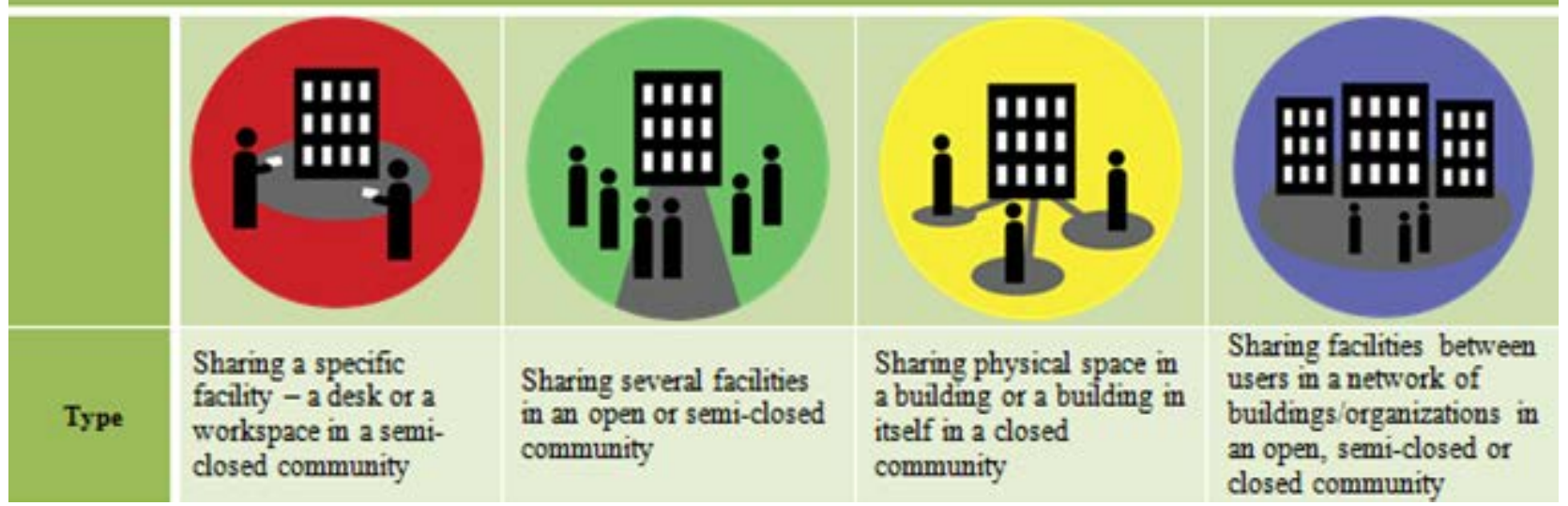

Figure 1: The Typology of shared use of facilities (Brinkø, Nielsen, \& Meel, 2015)

Accommodation of space as well as monitoring and optimising use/vacancy is a classical task within Facilities Management as a management discipline (Alexander 1992 and CEN/TC348 2006). In contrast to researchers like (Kovacs 2012) and (May 2015) who perceives low use rates as an optimisation challenge which can be described and solved by mathematical means, we focus on the socio-technical conditions for changing the situation. In a change management perspective it is important to know the stakeholders needs and motivations, why stakeholders perceptions of needs, motivations, opportunities and needs are the focus of this paper.

In the following we centre the focus on sharing facilities, and in particular meeting and conference facilities, between member organisations of the strategic urban network collaboration the Lyngby-Taarbæk City of Knowledge. The purpose is to assess the potential for sharing space in the City of Knowledge by studying the following: What is the members' motivation? What are eventual barriers? And how to organize the sharing?

\section{Methodology}

The current study is a part of the ph.d-study of "Shared Space in the City of Knowledge" by Rikke Brink $\varnothing$, focusing on providing new knowledge on shared spaces and how space sharing can help achieve optimised use of the built environment and the resource our buildings constitute. For the study presented in this paper, the attitude towards shared space in the Lyngby-Taarbæk City of Knowledge is studied through a mixed-method approach, with mixed method defined as "one complete method (as the core project) plus a different simultaneous and sequential supplemental strategy" (Morse, 2010). The mixed-method approach chosen is qualitative at its core but utilising quantitative methods in the form of surveys to gain broader insights into the topic, not otherwise possible with a pure qualitative study.

The approach has been a three step process structured as follows. The first step, survey 1 , investigates the City of Knowledge's member's attitude towards shared space in general. The second step, a workshop with the title "How can we become smarter at sharing?", was conducted as a part of a Lyngby-Taarbæk City of Knowledge members meeting following the survey, and utilised the survey result to further investigate the topics identified. Following the workshop a second survey focusing more specifically on the sharing of meeting and conference facilities, and the need for such spaces, was conducted to gain deeper insights in to this specific part of the topic of shared spaces.

A more detailed description of the separate steps in the process is presented in the following. 


\section{Surveys}

Questionnaires, or surveys, are as described by (Saunders, Lewis, \& Thornhill, 2016) well suited for descriptive research, where the purpose is mapping attitudes, opinions and organisational practices, making it a well-suited method for the purpose of the study presented here. The method was employed in order to gain insights on a number of specific questions related to shared spaces and the sharing of meeting facilities among a broader range of respondents than could be managed via interviews. That being said, the number of responses acquired is too low to draw any more general conclusions on the topic in relation to a wider population, and should rather be considered as a pilot study to determine the market's attitude toward the topic.

Two main surveys are included in this study. The first focusing on more general aspects related to sharing by use of questions such as; "what are you most likely to share with others?" and "what would you like to gain access to?". The purpose of this survey was to better understand how shared space was viewed among practitioners, what was perceived as barriers and what was perceived as motivational factors. The survey was sent out in September 2014 to the 152 recipients of the Knowledge City's newsletter and 32 replies were received, giving a response rate of $21 \%$. The survey consisted of a total of nine questions, six focusing on the subject of sharing and three on information regarding the respondents

The second survey was focused particular on the sharing of conference and meeting facilities, with questions such as; "Are you planning to host events / conferences / meetings that you do not have space for in-house?" and "If shared conference and meeting facilities were established in Lyngby, would you use them?". This survey was conducted in December 2015 and sent out to 64 recipients within the LyngbyTaarbæk City of Knowledge and received a total of 44 replies, giving a response rate of $68 \%$. It consisted of 10 questions in total, with eight focusing on meeting and conference facilities and two on information regarding the respondent.

\section{Workshop/focus group}

A workshop, along the lines of focus groups as described in (Saunders et al., 2016), is used to acquire more in-depth knowledge about the participants views on a number of different aspects within the field of shared space, by "encouraging interactions between participants as an effective means to articulate preheld views" (Saunders et al., 2016).

The workshop was as mentioned conducted as a part of a Lyngby-Taarbæk City of Knowledge members meeting in October 2014. 39 people from 21 different companies, municipalities and educational facilities participated in the workshop, where the findings from survey 1 was presented and used as a starting point to stimulate a discussion among the participants, in order to lay the grounds for the group work to be conducted. The workshop was used to explore the circumstances around the results from the survey, to better understand how to overcome the barriers and utilise the motivational factors in order to improve the processes involved in establishing and working with a shared space. The participants were divided in to groups of 6-10 individuals and asked to develop ideas, suggestions and answers to 4 predetermined questions to investigate the participant's visions, specific needs and ideas for how to organise shared space in the Knowledge City in practice. These questions were presented on posters handed out to each group, and each group was then instructed to place post-its with the results of their work on to the relevant part of the poster.

The results from the workshop was documented in a logbook, and later shared with the participants for feedback. 


\section{Results}

This paper presents the results of the before mentioned surveys and workshop. The main results from each of these data collection instances are presented, followed by a final summary of the key findings.

\section{Survey 1: Shared space in Lyngby Knowledge City}

The main results from survey 1 centre around four different aspects of sharing space;

- The overall attitude towards sharing in general?

- What facilities could be shared with others?

- What is the greatest obstacle for sharing?

- What is considered the greatest motivator?

What can be seen in Figure 2 is that while 73\% of the respondents are positive or very positive when asked how they feel about sharing space with others, only $10 \%$ are negative and none are very negative, $36 \%$ answer that they will not share anything when asked about specific possibilities for sharing.

The types of spaces/facilities that seem least problematic to share are support facilities such as bathrooms, receptions etc.; the types of facilities that do not require any significant interaction between the different parties involved in the sharing, and still only $32 \%$ say that they would consider sharing these facilities. If we move to core spaces/facilities such as laboratories, offices, etc. the percentage of positive replies drop to between 24 and $28 \%$, and if we look at support spaces such as storage etc. the positive replies drop even further to $20 \%$.

Regarding motivators and barriers, $62 \%$ of the respondents say that economy is the biggest motivator in sharing with others, and only $25 \%$ consider environmental considerations as an important motivator. $54 \%$ say that the limited availability following from shared space is the biggest obstacle, with the practical aspects involved; administration, access, security, cleaning and maintenance, following closely after. Illustrations of the results can be found in figure 2 . 


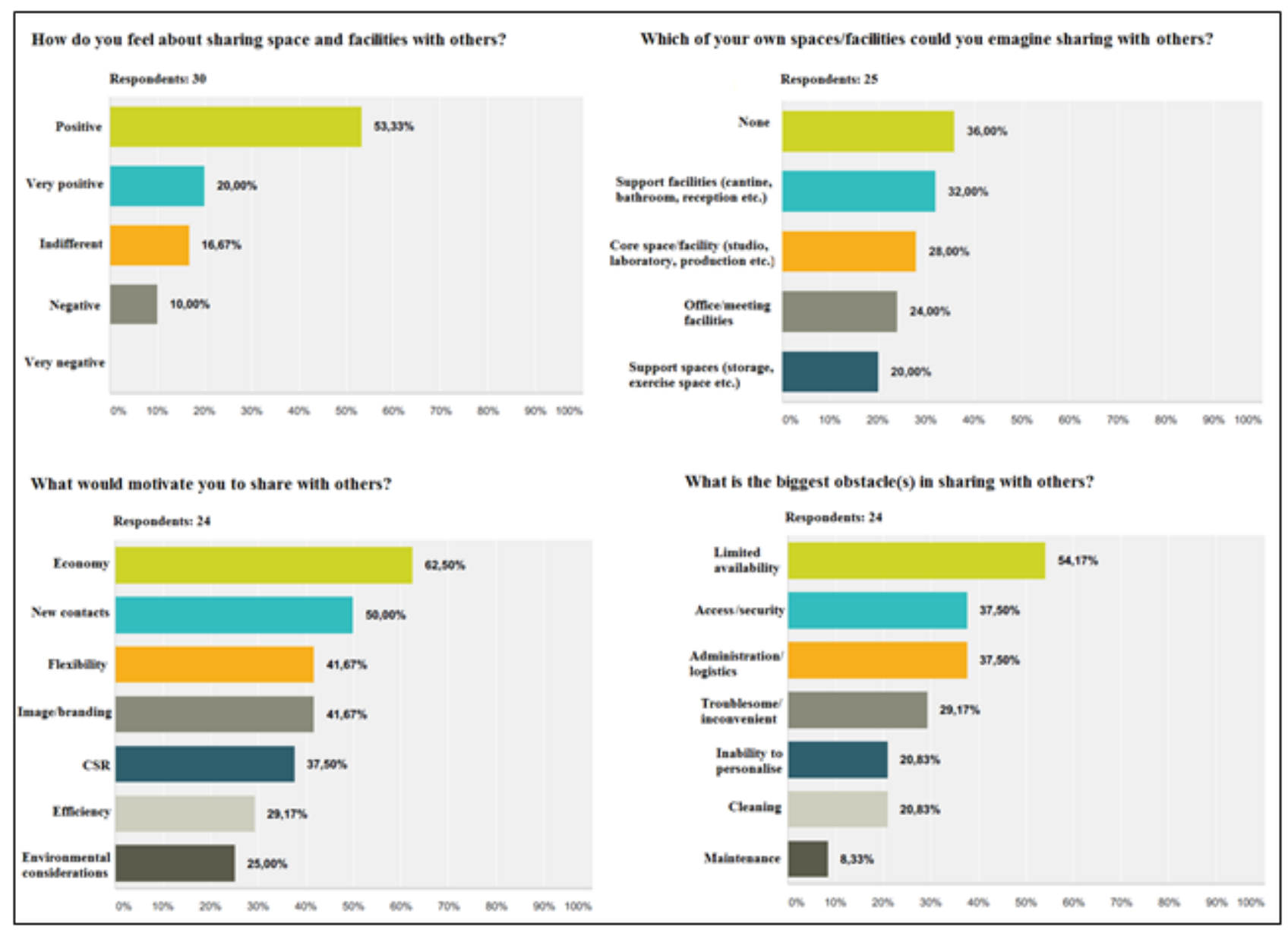

Figure 2: Four main results of survey 1: Shared space in Lyngby-Taarbæk City of Knowledge

\section{Workshop: How can we become smarter at sharing?}

The workshop, as mentioned, was conducted as part of a meeting for the Lyngby-Taarbæk City of Knowledge members with approximately 39 participants. The format was a poster containing the four main questions;

- If only I could...? To give the possibility to express visions and functions

- If only I knew...? To give the possibility to specify the need for information

- If only I had...? To give the possibility to identify means to facilitate the process of sharing

- Shared space I don't believe in it. To give the possibility to express critical concerns and scepticism

Participants were asked to discuss these in groups and write as many answers as possible to the questions on post-its and place them accordingly on the poster.

All posters and post-it's were collected in a large excel sheet, after which post-it's with similar answers were combined and the information condensed. From this a maximum of three main answers to each question were identified and collected in a single table summarising the main findings of the workshop. Among the results identified, clarity about the rules and regulations involved in sharing is singled out as one of the key problems with shared space in the current situation, and was mentioned in different variations under two of the four questions. The second issue identified as concerning actually finding possible shared spaces, and how to proceed with communications and facilitation of the sharing in practice.

Table 1 holds a summary of the collected answers to each question. 


\begin{tabular}{|c|c|c|c|c|}
\hline Nr. & If only I could... & If only I knew... & If only I had... & $\begin{array}{l}\text { Shared space I } \\
\text { don't believe in... }\end{array}$ \\
\hline 1 & $\begin{array}{l}\text { If only I could... merge city, } \\
\text { university and companies at the } \\
\text { local level... Then we would also } \\
\text { get more people and knowledge }\end{array}$ & $\begin{array}{l}\text { If only I knew... what spaces } \\
\text { I already have and what is } \\
\text { available 'out there' }\end{array}$ & $\begin{array}{l}\text { If only I had... a system } \\
\text { that could facilitate the } \\
\text { sharing }\end{array}$ & $\begin{array}{l}\text { Shared space I don't } \\
\text { believe in... there is too } \\
\text { much unknown } \\
\text { regarding rules and } \\
\text { regulations etc. }\end{array}$ \\
\hline 2 & $\begin{array}{l}\text { If only / could... Have access to an } \\
\text { overview of the legislative and } \\
\text { practical regulations involved- } \\
\text { clear guidelines }\end{array}$ & $\begin{array}{l}\text { If only I knew... where to } \\
\text { find shared spaces }\end{array}$ & $\begin{array}{l}\text { If only I had... help to } \\
\text { achieve clarity concerning } \\
\text { my actual needs and } \\
\text { current situation }\end{array}$ & $\begin{array}{l}\text { Shared space I don't } \\
\text { believe in... will people } \\
\text { be willing to } \\
\text { compromise in the long } \\
\text { run? }\end{array}$ \\
\hline 3 & $\begin{array}{l}\text { If only I could... have sufficient } \\
\text { flexibility for a space to be } \\
\text { adapted to many different uses }\end{array}$ & & $\begin{array}{l}\text { If only we had... better } \\
\text { cooperation and } \\
\text { communication across } \\
\text { institutions }\end{array}$ & \\
\hline
\end{tabular}

Table 1: Summery from workshop: How can we become smarter at sharing?

\section{Survey 2: Meeting and conference facilities in Lyngby Knowledge City}

The second survey, Survey 2, was conducted by the Lyngby-Taarbæk City of Knowledge secretariat, and the main results centre on three different aspects of sharing external meeting and conference facilities;

- The need for external facilities

- The desire to use external facilities

- What type of external facilities are preferred when needed

What can be seen in Figure 3 is that $64 \%$ of the respondents are planning future events which they do not have they space to host themselves, meaning that they will have to go outside their own company to fulfil the spatial need. The second question builds on from this need, and when asked if they would use some form of external meeting/conference facilities in the city of Lyngby if offered, $47 \%$ replies with a positive response and only $22 \%$ replies no.

The last result presented is focused on the distribution of preferred and previously used facilities when planning events. What can be seen here is that using one's own facilities is by far the preferred choice with app. $45 \%$, followed by external meeting/conference facilities with app. $35 \%$ and hotels with about $14 \%$. At the other end of the spectrum schools/universities score a 0 , and restaurants, sports facilities and other peoples/organisations facilities score 1-2\%.

Illustrations of the results can be seen in figure 3 . 


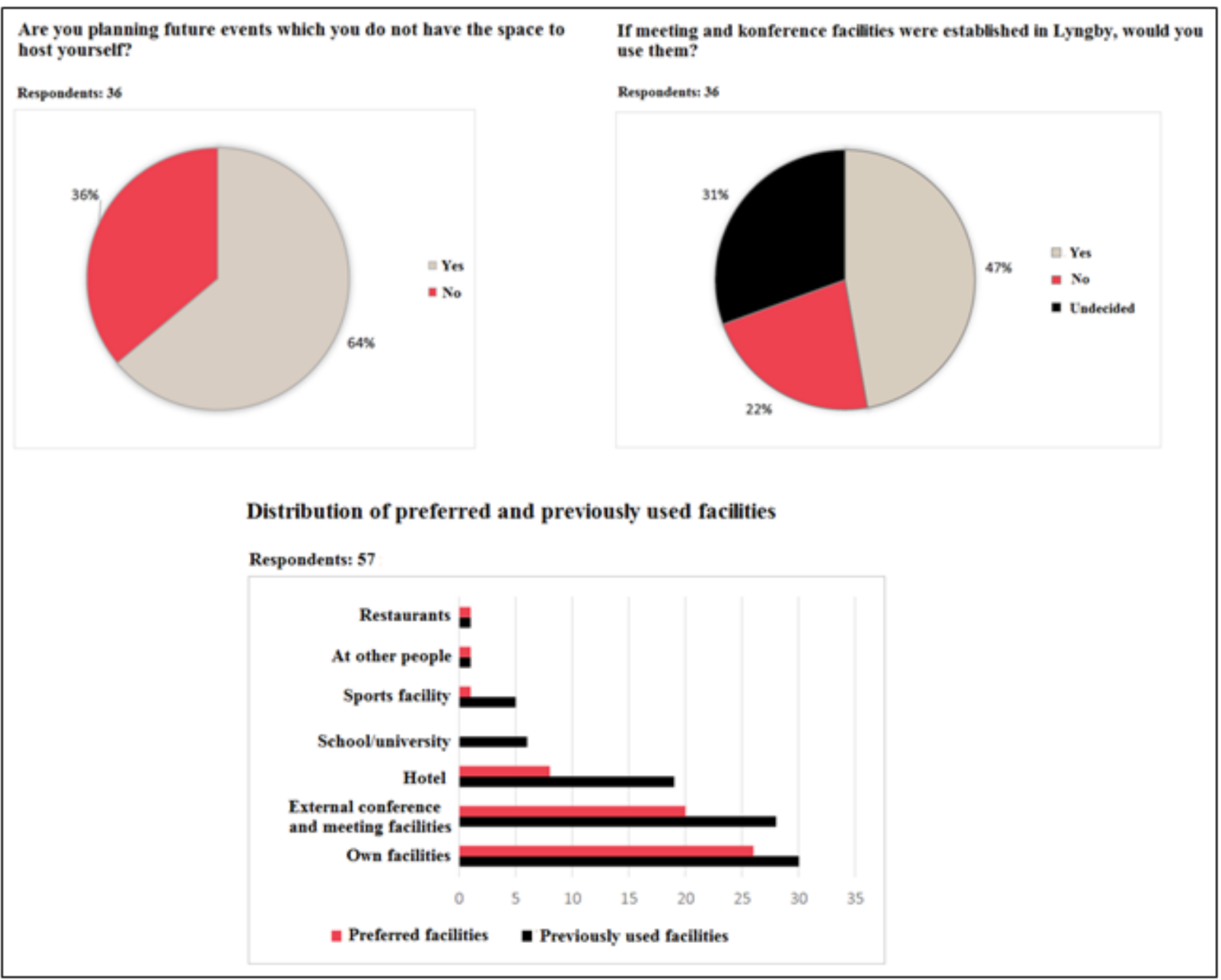

[Insert Figure 3: Three main results of survey 2: Meeting and conference facilities in Lyngby Knowledge City]

Questions about service levels and specifications of quality or quantity were addressed in survey 2 only at the level presented above.

\section{Discussion}

The purpose of the study is to investigate the attitude towards shared space in an urban context with a particular focus on meeting and conference facilities, and the potential for sharing meeting and conference space in the City of Knowledge. Based on the three data collection initiatives and analyses of these, a number of aspects concerning shared space and the sharing of meeting and conference facilities can be identified:

$>$ The general overall result being that the members of the Lyngby-Taarbæk City of Knowledge initially are very positive towards the concept of shared space.

$>$ There is a discrepancy between sharing in theory, where most are positive, and sharing in practice, where the informants become significantly more reserved.

This study is conducted in the Lyngby-Taarbæk City of Knowledge community which has collaboration and synergies as a common reference point. Compared to other cities and other contexts of building owners/event organizers we assume that if anything, our informants are more positive towards sharing space than others that have not engaged in a community like the City of Knowledge. However this has not been tested within the scope of this study. The economic context and the general access to space will also 
impact on the burning platform, where shared space can be seen as a strategy for intensifying the use of space, to stimulate innovation and to gain access to space without ownership or leasing contracts.

For other cities who, like Lyngby would like to stimulate collaboration and sharing in an urban context it is important to consider:

$>$ What are the motivations for sharing?

$>$ Are the practicalities in place or is there a need of systems and or organisations to facilitate information about available space and booking?

$>$ How can the process grow from a need driven bottom up perspective, which is the spirit of the sharing economy?

$>$ Building a collective vision of sharing might be a Sisyphus task, and is for sure an ongoing process. In Lyngby the knowledge city strategy is giving a shared vision, and sharing facilities is a step in realizing this vision.

During our studies we have found that it is the politicians in the municipality and the municipal FM organisations who are most keen on sharing their facilities to increase the use of the public buildings. In this respect our results are thought provoking as schools/universities/sports facilities are the least preferred space for organizing external meetings and conferences, compared to professional meeting and conference facilities or own space. Probably because the service level in the public buildings or at restaurants are perceived as too low and with insufficient standards regarding e.g. physical appearance, audio visual equipment, Wi-Fi, transparent costs and easy payment, catering, help at hand during an event, catering, and flexible rooms of various sizes.

One should also be aware that established commercial conference facilities providers are likely to fight against development like this as e.g. the established taxi companies sees Uber as a threat to their business. This has not yet been the case in Lyngby, but it is certainly a concern of some local stakeholders, and a concern that we understand in full.

\section{Limitations}

There is a number of limitations to the study presented in this paper. First of all, the study has only been conducted in the Lyngby-Taarbæk City of Knowledge; a case population that must be expected to be slightly biased on the topic due to the fact that they have all already made the conscious choice of joining such an association, focused on collaboration and knowledge sharing.

Second, there is the aspect of the relatively low number of respondents, especially in relation to the first survey conducted. This means that no broader conclusions can be drawn to a wider population with any statistical certainty, and the study should therefore as mentioned instead be viewed as a pilot to determine the market attitude towards the topic.

\section{Conclusion}

The purpose of this study is to investigate the attitude towards shared space in an urban context with a particular focus on meeting facilities. The background was to intensify the use of buildings and in particular special facilities for larger meetings and conferences, as all buildings which are heated, cooled and maintained but remain largely underused over time are not environmentally or economically efficient and because giving others access to underutilised space can stimulate synergies, innovation and attractiveness of buildings and cities. 
We found a positive attitude towards the concept of shared space. However, the survey particular on sharing of conference facilities showed a less positive attitude which leads us to conclude that the general attitude is positive towards sharing, but asked specifically about motivations and willingness to share, there is a less positive attitude.

This study show that the members of the Lyngby-Taarbæk City of Knowledge collaboration are very positive towards the concept of shared space, but more reluctant about sharing own facilities. A majority of the informants are often using externally owned facilities for meetings and events, and they prefer professional meeting facilities to schools, universities and sports facilities. This point to a need for developing relevant service concepts, if a shared space strategy with focus on meeting facilities were to be used to increase the use rate of existing buildings not already intended for this use.

\section{References:}

Alexander, K (1992) "Facilities Management Practice", Facilities, Vol.10 Iss 5 pp. 11-18

Brink $\varnothing, R$ \& Nielsen, SB (2015) "Shared space in a municipal sports facility: The case of Lyngby Idraetsby". In K Alexander \& I Price (eds), Research Papers. Advancing Knowledge in Facilities Management: People make Facilities Management. EuroFM. EuroFM Research Papers.

Brinkø, R., Nielsen, S.B., Meel, J.v. (2015) "Access over ownership - a typology of shared space", Facilities, Vol. 33 Iss: 11/12, pp.736 - 751 .

Cabeza, L.F., Rincón, L., Vilariñob, V. Péreza, G. and Castell, A. (2014) “Life cycle assessment (LCA) and life cycle energy analysis (LCEA) of buildings and the building sector: A review". Renewable and Sustainable Energy Reviews. Elsevir.

CEN/TC348 (2006) “Facilities Management - Terms and definitions, EN 15221-1".

Kovacs, A. (2012) "MoreSpace - Strategies for an Intensive Use of Built Environment over Time". Proceedings of the $11^{\text {th }}$ EuroFM research symposium, 24-25. May 2012 in Copenhagen, Denmark. Polyteknisk Forlag.

Kojo, I. and Nenonen, S. (2016) "Typologies for co-working spaces in Finland - what and how?". Facilities, Vol. 34 Iss: 5/6, pp.302-313.

May, M. (2015) "Economic Space Utilization and Sustainability by IT-based Optimization", International Journal of Facilities Management. Vol 6 No 1.

Meel, JV \& Brinkø, R (2014) “Working apart together”. EuroFM Insight, no. September, pp. 10-11.

Nielsen, S.B., Junghans, A. and Jones, K. (2016) “Chapter 15 Sustainability”. In: Facilities Management and Corporate Real Estate Management as Value Drivers: How to Manage and Measure Adding Value, by P.A. Jensen and T.v.d. Voordt. Routledge. (forthcoming)

Rytkönen, E. (2016) "University campus management dynamics in spatial transformation: Systemic facilitation of interdisciplinary learning communities". Doctoral Dissertation. Department of Civil and Structural Engineering. Aalto University. Finland.

Atkin, B., \& Brooks, A. (2015). Total Facility Management (4th ed.). Wiley-Blackwell.

Becker, F. (1990). The total workplace. Facilities, 8(3), 9-14. 
Becker, F. D., \& Steele, F. (1995). Workplace by design: mapping the high performance workscape. JosseyBass Publishers.

Brink $\varnothing$, R., Nielsen, S. B., \& Meel, J. Van. (2015). Access over ownership - a typology of shared space. Facilities.

Duffy, F., Craig, D., \& Gillen, N. (2011). Purpose, process, place: design as a research tool. Facilities, 29(3/4), 97-113. https://doi.org/10.1108/02632771111109243

Duffy, F., \& Powell, K. (1997). The new office. Conran Octopus.

Fawcett, W. H. (2009). Optimum capacity of shared accommodation: yield management analysis. Facilities, 27(9/10), 339-356. https://doi.org/10.1108/02632770910969595

Gaffikin, F., \& Morrissey, M. (2011). Planning in Divided Cities: Collaborative Shaping of Contested Space. Planning in Divided Cities: Collaborative Shaping of Contested Space. https://doi.org/10.1002/9781444393200

Jensen, P. A. (2008). Facilities Management for students and practitioners. Centre For Facilities Management - Realdania Research.

Khamkanya, T., \& Sloan, B. (2009). Flexible working in Scottish local authority property: Moving on to the highest flexibility level. International Journal of Strategic Property Management, 13(1), 37-52. https://doi.org/10.3846/1648-715X.2009.13.37-52

Lee, Y., Kim, H., \& Yoon, H. (2010). Spatial Representation of Community Shared Spaces Preferred by Residents. Indoor and Built Environment, 19(1), 163-174. https://doi.org/10.1177/1420326X09358023

May, M. (2014). Modeling and Optimization in Strategic Space Management. FMJ IFMA, (April 2014).

Morse, J. M. (2010). Simultaneous and Sequential Qualitative Mixed Method Designs. Qualitative Inquiry, 16(6), 483-491. https://doi.org/10.1177/1077800410364741

Rafferty, G. (2012). Embracing the Creation of Shared Space : Considering the Potential Intersection between Community Planning and Peace-building. Space and Polity, 16(2), 197-213.

Saunders, M., Lewis, P., \& Thornhill, A. (2016). Research methods for business students (7th ed.). Pearson.

Walsh, B. (2011) "10 Ideas That Will Change the World". Time. Retrieved from

http://www.time.com/time/specials/packages/article/0,28804,2059521_2059717_2059710,00.html 